\title{
Serological studies on 40 cases of mumps virus infection
}

\author{
R FREEMAN* AND MH HAMBLING
}

From Leeds Regional Public Health Laboratory, Bridle Path, York Road, Leeds, UK

SUMMARY The results of serological study of 40 cases of mumps virus infection are presented. Mumps virus was isolated from 20 of the patients studied and antibodies to the $V$ antigen, the $S$ antigen, and the haemagglutination antigen were performed in all cases. Analysis of these results shows that estimation of all three types of antibody is necessary to confirm the diagnosis in the maximum number of instances and that the long-accepted view that a characteristic pattern of antibody response is typical of the acute illness (namely, anti-S appearing earlier and in greater titre than anti-V) is questionable.

It is recommended that serological tests for evidence of infection with mumps virus should include estimation of complement-fixing antibodies to both the virus particle (V) antigen and the soluble (S) antigen of the virus. ${ }^{1}$ This view has been held for some time and by other authors, for instance, Lennette and Schmidt. ${ }^{2}$ Furthermore, it is held by these authors that antibody to the $S$ antigen appears early in the course of the disease (often within two to three days after the onset of clinical symptoms) whereas antibody to the $\mathrm{V}$ antigen appears much later. This disparity in the levels of the two antibodies in the early part of the illness, namely, $S$ antibody being present earlier and in higher titre than $\mathrm{V}$ antibody, has been taken to be so characteristic of the acute illness that a presumptive diagnosis can be made in clinically suspicious cases. ${ }^{2}$

A brief survey of the serological results obtained in confirmed and suspected cases of mumps virus infection did not seem to support the foregoing statements and led to a more detailed investigation, the results of which are reported below.

\section{Methods and material}

Acute and convalescent serum samples were available from 40 patients and had been stored at $-20^{\circ} \mathrm{C}$ until recall for this investigation. Brief details of the 40 patients from whom the specimens were obtained are given in Table 1, together with the results of virus isolation tests in those patients from whom speci-

* Present address: Department of Microbiology, Freeman Hospital, Freeman Road, High Heaton, Newcastle upon Tyne

Received for publication 26 June 1979 mens were sent. Acute and convalescent serum samples were titrated in parallel from an initial dilution of 1 in 8 to a final dilution of 1 in 512 in microtitre plates. Detection of complement-fixing antibody to $\mathrm{V}$ and $\mathrm{S}$ antigens was by a standard technique, ${ }^{3}$ adapted for use in microtitre plates. Although sera showing fixation to levels beyond 1 in 512 were occasionally encountered, such results have been expressed as greater than or equal to 1 in 512 in order to allow the inclusion of several samples, insufficient of which remained to allow determination of the final end-point. All results were obtained on at least two separate testing occasions before being accepted as reproducible.

Haemagglutination-inhibiting (HAI) antibody to mumps virus was measured by a microtitre method, using a virus dose of 4 haemagglutinating units (4HAU) of an antigen obtained by serial passage in fertile hens' eggs of the Enders strain of mumps virus. The passage was by the allantoic route. All sera were pretreated with receptor-destroying enzyme (RDE) and tested at dilutions from 1 in 10 to 1 in 640 , acute and convalescent samples from the same patient being tested in parallel. Finally, a selection of the serum samples was re-tested for complement-fixing antibody to the $\mathrm{V}$ and $\mathrm{S}$ antigens using antigens prepared in the laboratory according to the methods of Lennette and Schmidt. ${ }^{2}$ In all instances, the results were not significantly different from those obtained with the standard antigens. These last results, therefore, are not presented below.

\section{Results}

Table 1 lists brief details of the $\mathbf{4 0}$ patients from 
Table 1 Clinical diagnosis, patient details, and results of virus isolation tests in 40 patients with mumps virus infection

\begin{tabular}{|c|c|c|c|c|c|c|}
\hline \multirow[t]{2}{*}{ Patient } & \multirow[t]{2}{*}{$\operatorname{Age}(y r)$} & \multirow[t]{2}{*}{ Sex } & \multirow[t]{2}{*}{ Diagnosis } & \multicolumn{3}{|c|}{ Virus isolation from: } \\
\hline & & & & Throat & $C S F$ & Urine \\
\hline 1 & 8 & $\mathbf{M}$ & Parotitis & $*$ & $*$ & $*$ \\
\hline 2 & 5 & $\mathbf{F}$ & Meningitis & + & $*$ & $*$ \\
\hline 3 & 18 & $\mathbf{M}$ & Meningitis & + & * & + \\
\hline 4 & 30 & $\mathbf{F}$ & Rash. Pregnart & $*$ & $*$ & $*$ \\
\hline 5 & 8 & $\mathbf{F}$ & Meningıtis & + & $*$ & $*$ \\
\hline 6 & 5 & $\mathbf{F}$ & Mening 1 tis & $*$ & + & $*$ \\
\hline 7 & 5 & $\mathbf{M}$ & Meningitis & $*$ & + & $*$ \\
\hline 8 & $6 / 12$ & $\mathbf{M}$ & Meningitis & $*$ & - & $\bullet$ \\
\hline 9 & 5 & $\mathbf{M}$ & Meningitis & - & $*$ & $*$ \\
\hline 10 & 3 & $\mathbf{M}$ & Meningitis & $*$ & + & $*$ \\
\hline 11 & 1 & $\mathbf{M}$ & Parotitis & + & $*$ & $*$ \\
\hline 12 & 20 & $\mathbf{M}$ & $\begin{array}{l}\text { Meningitis } \\
\text { Orchitis } \\
\text { Parotitis }\end{array}$ & $*$ & - & $*$ \\
\hline 13 & 7 & $\mathbf{M}$ & Meningitis & + & $*$ & $*$ \\
\hline 14 & 10 & $\mathbf{M}$ & Meningitis & + & + & $*$ \\
\hline 15 & 6 & $\mathbf{M}$ & Meningitis & $*$ & + & $*$ \\
\hline 16 & 3 & $\mathbf{M}$ & Meningitis & $*$ & - & $*$ \\
\hline 17 & 1 & $\mathbf{M}$ & Parotitis & $*$ & $*$ & $*$ \\
\hline 18 & 27 & $\mathbf{F}$ & $\begin{array}{l}\text { Meningitis } \\
\text { Pregnant }\end{array}$ & $*$ & * & $*$ \\
\hline 19 & 6 & $\mathbf{M}$ & Meningitis & + & + & + \\
\hline 20 & 5 & $\mathbf{F}$ & Meningitis & + & + & $*$ \\
\hline 21 & 19 & $\mathbf{M}$ & Parotitis & - & $*$ & $*$ \\
\hline 22 & 30 & $\mathbf{M}$ & Meningitis & $*$ & $*$ & + \\
\hline 23 & 4 & $\mathbf{M}$ & Meningitis & + & $*$ & + \\
\hline 24 & 8 & $\mathbf{M}$ & Meningitis & $*$ & $*$ & $*$ \\
\hline 25 & 9 & $\mathbf{F}$ & Meningitis & + & $*$ & $*$ \\
\hline 26 & $3 \frac{1}{2}$ & $\mathbf{F}$ & Meningitis & - & - & - \\
\hline 27 & $9^{-}$ & $\mathbf{M}$ & Meningitis & $*$ & $*$ & $*$ \\
\hline 28 & 6 & $\mathbf{M}$ & Meningitis & $*$ & - & $*$ \\
\hline 29 & 27 & $\mathbf{M}$ & Meningitis & - & $*$ & $*$ \\
\hline 30 & 5 & $\mathbf{F}$ & Parotitis & $\bullet$ & $*$ & $*$ \\
\hline 31 & $?$ & $\mathbf{F}$ & Meningitis & $*$ & $*$ & $*$ \\
\hline 32 & 7 & $\mathbf{M}$ & Meningitis & $*$ & + & + \\
\hline 33 & $?$ & $\mathbf{F}$ & Parotitis & + & $*$ & + \\
\hline 34 & 2 & $\mathbf{M}$ & Meningitis & + & + & $*$ \\
\hline 35 & 4 & $\mathbf{M}$ & Meningitis & $*$ & - & $*$ \\
\hline 36 & 10 & $\mathbf{M}$ & Meningitıs & $*$ & - & $*$ \\
\hline 37 & 5 & $\mathbf{F}$ & Parotitis & $*$ & $*$ & - \\
\hline 38 & 4 & $\mathbf{F}$ & Meningitis & $*$ & + & $*$ \\
\hline 39 & 2 & $\mathbf{M}$ & Meningitis & $*$ & + & $\bullet$ \\
\hline 40 & $5 \underline{2}$ & $\mathbf{M}$ & Meningitis & - & - & $*$ \\
\hline
\end{tabular}

+Mumps virus isolated; - no virus isolated; *no specimen received.

whom specimens were available and the results of virus isolation tests if these were performed. Thus, in 32 patients, one or more specimens suitable for virus culture was submitted, and in 20 of these patients mumps virus was found. The series of patients studied reflects the usual finding that the commonest feature of mumps virus infection necessitating admission to hospital is meningitis. Thus, this study may not be representative of the findings in a community experiencing mumps virus infection and in which the full spectrum of clinical illness is included.

Table 2 details the serological findings in those 20 patients from whom the virus was recovered, and Table 3 the serological findings in the remaining 20 patients in whom the evidence for infection with mumps virus is solely on serological grounds, the virus not having been recovered.

Figure 1 shows the distribution of antibody levels to all three antigens in both acute and convalescent serum samples, and Fig. 2 relates the titre of antibody to the $\mathrm{V}$ antigen to that of the $\mathrm{S}$ antigen on the same serum sample, whether acute or convalescent.

\section{Discussion}

The first and possibly the most important point to be made from the results of this study is that the recommendation that both $\mathrm{V}$ and $\mathrm{S}$ antigens should be routinely employed in testing for serological evidence- 
Table 2 Serological findings in 20 patients from whom mumps virus was isolated from one or more sites

\begin{tabular}{|c|c|c|c|c|}
\hline \multirow[t]{2}{*}{ Patient } & \multirow{2}{*}{$\begin{array}{l}\text { Day of } \\
\text { illness }\end{array}$} & \multicolumn{3}{|c|}{ Antibody level to* (antigen): } \\
\hline & & $V$ & $S$ & $H A I$ \\
\hline \multirow[t]{2}{*}{2} & 1 & 128 & 64 & 10 \\
\hline & 8 & 128 & 64 & $\delta ?$ \\
\hline \multirow[t]{2}{*}{3} & 2 & 8 & 8 & $<10$ \\
\hline & 9 & 256 & 32 & 40 \\
\hline \multirow[t]{2}{*}{5} & 2 & 16 & $<8$ & $<10$ \\
\hline & 8 & 128 & 32 & 20 \\
\hline \multirow[t]{2}{*}{6} & 4 & 8 & $<8$ & $<10$ \\
\hline & 9 & 64 & 32 & 10 \\
\hline \multirow[t]{2}{*}{7} & 1 & 64 & 16 & $<10$ \\
\hline & 9 & $>512$ & 128 & 40 \\
\hline \multirow[t]{2}{*}{10} & 3 & 128 & $<8$ & $<10$ \\
\hline & 15 & 256 & 128 & 20 \\
\hline \multirow[t]{2}{*}{11} & 2 & $<8$ & 8 & $<10$ \\
\hline & 6 & 128 & 32 & ins \\
\hline \multirow[t]{2}{*}{13} & 2 & 32 & 32 & 20 \\
\hline & $2 \overline{4}$ & 256 & 256 & 160 \\
\hline \multirow[t]{2}{*}{14} & 3 & 16 & $<8$ & 10 \\
\hline & 10 & .512 & 64 & 40 \\
\hline \multirow[t]{2}{*}{15} & 2 & 16 & 8 & $<10$ \\
\hline & 16 & 128 & 64 & 20 \\
\hline \multirow[t]{2}{*}{19} & 2 & $<8$ & 8 & 10 \\
\hline & 8 & $>512$ & 32 & 20 \\
\hline \multirow[t]{2}{*}{20} & 2 & $<8$ & 16 & $<10$ \\
\hline & 10 & 64 & 128 & 20 \\
\hline \multirow[t]{2}{*}{22} & 3 & 128 & 8 & $<10$ \\
\hline & 25 & $>512$ & 128 & 160 \\
\hline \multirow[t]{2}{*}{23} & 2 & 16 & $<8$ & 10 \\
\hline & 7 & 128 & 128 & ins \\
\hline \multirow[t]{2}{*}{25} & 2 & 16 & $<8$ & $<10$ \\
\hline & 11 & 64 & 32 & 10 \\
\hline \multirow[t]{2}{*}{32} & 2 & 16 & $<8$ & 10 \\
\hline & 12 & 32 & 32 & ins \\
\hline \multirow[t]{2}{*}{33} & 2 & 8 & 8 & $<10$ \\
\hline & 12 & 64 & 32 & 40 \\
\hline \multirow[t]{2}{*}{34} & 2 & 8 & $<8$ & $<10$ \\
\hline & 9 & $>512$ & 128 & 40 \\
\hline \multirow[t]{2}{*}{38} & 6 & 8 & $<8$ & $<10$ \\
\hline & 12 & $>512$ & 64 & 40 \\
\hline \multirow[t]{2}{*}{39} & 3 & 64 & 32 & $<10$ \\
\hline & 12 & 128 & 128 & 80 \\
\hline
\end{tabular}

* Reciprocal of serum dilution.

of infection with mumps virus is clearly supported. Thus, in Table 2 patients $2,39,10$, and 32 would not have been diagnosed on serological criteria had testing been confined to the $\mathrm{V}$ antigen alone, yet mumps virus was isolated from the spinal fluid. Similarly, in Table 3 patients 4,26 , and 29 would not have been diagnosed by serology to the $\mathrm{V}$ antigen alone, although, since the virus was not isolated from either patient, proof that they had mumps virus infection is not absolute. Equally important is the finding that the HAI test makes a valuable contribution in mumps virus serology. Thus, in Table 2, patient 2 , from whom the virus was isolated, could not be shown to have serological evidence of the infection (by the criterion of a fourfold, or greater, increase in specific antibody level) by testing to either $\mathrm{V}$ or $\mathbf{S}$ antigen, but a significant increase in antibody was easily detected by the HAI method. Again, of the three patients cited earlier in Table 2, in whom testing to the $\mathrm{S}$ antigen gave a serological diagnosis not possible using the $\mathrm{V}$ antigen alone, the HAI test also confirmed the diagnosis in patients 10 and 39 . In patient 32, insufficient serum remained for the HAI test to be performed. In Table 3 the HAI test confirmed the diagnosis suggested by testing to the $S$ antigen in patient 4 , but although a small rise in HAI antibody was obtained in patient 29 it was not quite significant by the accepted criteria. However, in patient 21 , the HAI test was the only method showing an unequivocal fourfold rise in specific antibody.

Table 3 Serological findings in 20 patients with clinical evidence of mumps virus infection but in whom the virus was not isolated

\begin{tabular}{|c|c|c|c|c|}
\hline \multirow[t]{2}{*}{ Patient } & \multirow{2}{*}{$\begin{array}{l}\text { Day of } \\
\text { illness }\end{array}$} & \multicolumn{3}{|c|}{ Antibody level to* (antigen): } \\
\hline & & $V$ & $S$ & $H A I$ \\
\hline \multirow[t]{2}{*}{1} & 2 & 16 & 16 & $<10$ \\
\hline & $8^{* *}$ & 128 & 128 & 20 \\
\hline \multirow[t]{3}{*}{4} & incub & 32 & $<8$ & $<10$ \\
\hline & 5 & 64 & 32 & 80 \\
\hline & 26 & 64 & 32 & 40 \\
\hline \multirow[t]{2}{*}{8} & 2 & $<8$ & $<8$ & 20 \\
\hline & 21 & 256 & 128 & 20 \\
\hline \multirow[t]{2}{*}{9} & 4 & 8 & 8 & $<10$ \\
\hline & 15 & 256 & 32 & 80 \\
\hline \multirow[t]{3}{*}{12} & 7 & 32 & 8 & 10 \\
\hline & 8 & 32 & 8 & 10 \\
\hline & 15 & 128 & 64 & 80 \\
\hline \multirow[t]{2}{*}{16} & 7 & 64 & 32 & ins \\
\hline & 19 & $>512$ & $>512$ & 80 \\
\hline \multirow[t]{2}{*}{17} & 2 & $<8$ & $<8$ & $<10$ \\
\hline & 30 & 64 & 16 & 20 \\
\hline \multirow[t]{2}{*}{18} & 4 & 32 & 8 & $<10$ \\
\hline & 21 & 256 & 64 & 20 \\
\hline \multirow[t]{2}{*}{21} & 8 & 64 & 32 & 20 \\
\hline & 22 & 128 & 64 & 80 \\
\hline \multirow[t]{2}{*}{24} & 3 & 32 & 16 & $<10$ \\
\hline & 30 & 128 & 64 & 40 \\
\hline \multirow[t]{2}{*}{26} & 2 & 64 & 64 & $<10$ \\
\hline & 6 & 64 & 128 & 20 \\
\hline \multirow[t]{2}{*}{27} & 1 & 32 & 8 & $<10$ \\
\hline & 23 & $>512$ & 64 & 20 \\
\hline \multirow[t]{2}{*}{28} & 4 & 32 & 16 & 20 \\
\hline & 14 & 256 & 128 & 80 \\
\hline \multirow[t]{2}{*}{29} & 2 & 128 & 32 & 10 \\
\hline & 25 & 256 & 128 & 20 \\
\hline \multirow[t]{2}{*}{30} & 9 & 32 & 32 & 10 \\
\hline & 16 & 128 & 128 & 40 \\
\hline \multirow[t]{2}{*}{31} & 3 & 64 & $<8$ & $<10$ \\
\hline & 24 & 256 & 64 & 80 \\
\hline \multirow[t]{2}{*}{35} & 2 & 64 & 32 & ins \\
\hline & 30 & $>512$ & 128 & 20 \\
\hline \multirow[t]{2}{*}{36} & 8 & 32 & $<8$ & 10 \\
\hline & 21 & 128 & 32 & 40 \\
\hline \multirow[t]{2}{*}{37} & 4 & 16 & $<8$ & $<10$ \\
\hline & 9 & 256 & 64 & 20 \\
\hline \multirow[t]{2}{*}{40} & 1 & 16 & $<8$ & $<10$ \\
\hline & 8 & 64 & 32 & 20 \\
\hline
\end{tabular}

* Reciprocal of serum dilution.

* This specimen was submitted for routine rubella screening before the patient fell ill but after known contact with mumps! incub = incubation

ins $=$ insufficient 

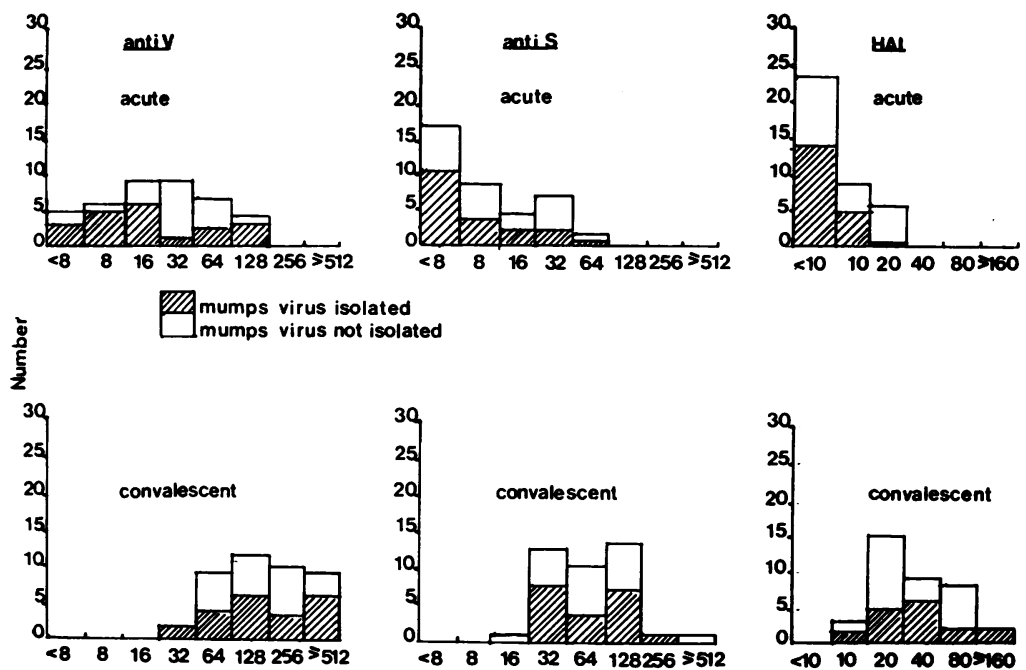

Fig. 1 Distribution of antibody titres (reciprocal of serum dilution) in acute and convalescent samples.

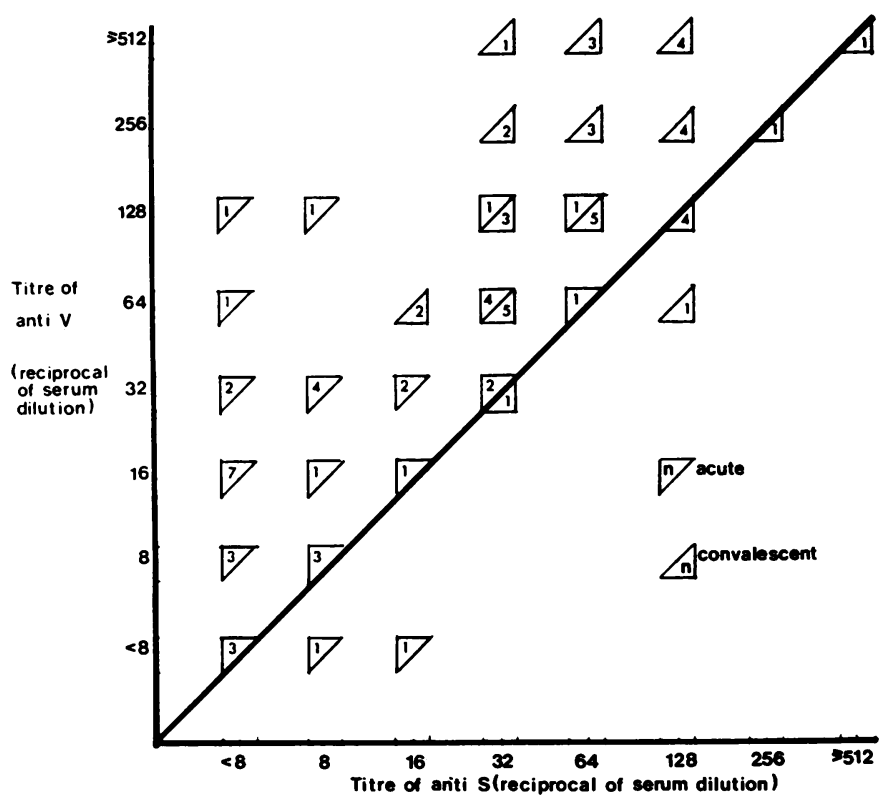

Fig. 2 Comparison of anti- $V$ and anti-S titres.

Therefore, while the recommendation that both $\mathrm{V}$ and $S$ antigens be tested in parallel is supported, this study also suggests that it should be extended and that the HAI method should be more frequently used. The test is simple to perform and it is within the capacity of any competent virological laboratory. While routine use of the HAI test is probably not necessary, it should be available for testing the sera of clinically suspicious cases in which complementfixation tests have failed to give clearcut results.

Turning to the specific question posed in the introduction to this paper, it is clear that the results obtained in this study do not support the accepted view that antibody to the $S$ antigen arises earlier and more rapidly in developing cases of mumps virus infection. Indeed, Fig. 1 shows that in the vast 
majority of the cases considered here antibody to the $V$ antigen appeared earlier than that to the $S$ antigen. As is also shown in Fig. 1, this is true even if consideration is restricted to those patients from whom the virus was isolated. Similarly, Fig. 2 demonstrates that production of antibody to the $\mathrm{V}$ antigen continues to be produced in excess of that to the $S$ antigen, since when direct comparison of the two antibody levels on individual serum samples is made, the $\mathrm{V}$ antibody exceeds the $\mathrm{S}$ antibody in all but a few cases whether the sample is taken early in the illness or in convalescence. The statement that $\mathbf{S}$ antibody is more commonly present in acute serum than $\mathrm{V}$ antibody is attributed to Henle et al. ${ }^{4}$ It is not clear from this source what the total number of cases studied was, but it is certain that a substantial number of verified cases was investigated. Several explanations for the discrepancy can be put forward.

Firstly, there may be a difference in the antigens used. This seems unlikely since the standard antigens employed in the present study are prepared on very similar lines to those used by Henle et al. ${ }^{4}$ In any case, a proportion of the sera in this study were retested with antigens prepared strictly by the protocol detailed by Henle in a standard text, ${ }^{2}$ and similar results were obtained. Secondly, Henle et al. ${ }^{4}$ make the point that, on several occasions, they encountered acute serum samples in which antibody to the $S$ antigen showed marked pro zononing and partial fixation of complement over the low initial dilutions. Again, it is impossible for their report to determine the frequency of this phenomenon, but it has been observed by others, notably Enders et al. ${ }^{5}$ in studies using extracts of monkey parotid gland as a serological antigen (antigen thought to be predominantly of the $S$ type). No such phenomenon was encountered in the present study, although had it occurred it is clear from the above reports that the procedures adopted of titrating the acute and convalescent sera in parallel at dilutions ranging from 1 in 8 to 1 in 512 would have revealed this. Thus, it seems that this explanation is unlikely.

A third possible explanation is that the epidemic strains of the mumps virus studied by Henle et al. ${ }^{4}$ and that responsible for the local outbreak from which these present cases are taken are antigenically different. This appears very unlikely, mumps virus being accepted as antigenically homogeneous and stable. ${ }^{1}$ The possibility that the Enders strain used for the preparation of antigens has subtly altered through serial passage over the years could be excluded by direct comparisons on the materials and sera of the two eras. It is known that previous experience of infection with parainfluenza viruses can modify and complicate the serological response to mumps virus infection, ${ }^{2}$ and it remains possible that this factor may have played a larger role in one series than in the other. It is also certain that the present series represents a subpopulation of the community infected with mumps virus at the time, in that it is predominantly hospital inpatients and thus represents the severest end of the clinical spectrum. This may not be so with the series studied by Henle et al. 4

Thus, it appears that no obvious explanation for the differences exists. It is to be hoped that other laboratories involved in testing sera for evidence of mumps virus infection will provide confirmation of these findings, or refute them, and that by so doing some explanation will be found. Meanwhile, it is suggested that clinicians and laboratory workers involved in this field interpret the results of mumps virus serology with caution and that the previous practice of making a presumptive diagnosis based on the results of serological tests on the acute serum specimen be reviewed. On the results presented here such a diagnosis seems unwarranted.

The provision of complement-fixing antigens used in this study by Dr C M Patricia Bradstreet, Standards Laboratory, Central Public Health Laboratory, Colindale is gratefully acknowledged. We are also indebted to Mr G Chance and Miss B M McLean for excellent technical assistance.

\section{References}

${ }^{1}$ Cruickshank R, Duguid J P, Marmion B P, Swain R H A. Medical Microbiology: A Guide to the Laboratory Diagnosis and Control of Infection. 12th ed. London and New York: Churchill Livingstone, 1973: 448-450.

${ }^{2}$ Lennette E H, Schmidt N J. Diagnostic Procedures for Viral and Rickettsial Diseases. 3rd ed. New York: American Public Health Association, 1964: 487-509.

${ }^{3}$ Bradstreet C M P, Taylor C E D. Technique of complement-fixation test applicable to the diagnosis of virus diseases. Monthly Bull Minist Health (London) 1962; 21: 96-104.

${ }^{4}$ Henle G, Harris S, Henle W. The reactivity of various human sera with mumps complement-fixation antigens. $J$ Exp Med 1948; 88: 133-147.

${ }^{5}$ Enders J F, Cohen S, Kane L W. Immunity in mumps. II. The development of complement-fixing antibody and dermal hypersensitivity in human beings following mumps. $J$ Exp Med 1945; 81: 119-135.

Requests for reprints to: Dr R Freeman, Department of Microbiology, Freeman Hospital, Freeman Road, High Heaton, Newcastle upon Tyne, UK. 